\title{
'Disastrologies'
}

'Disastrologies' - would be the title, do you like it?

I think it would suit us well. (Jacques Derrida, September $\left.27^{\text {th }} 1977\right)^{1}$

These words, I chanced upon them, in a post-card, a strange post-card since nowhere does its author, Monsieur D., disclose to whom it is written. It is true, I accept, that no-one can ever finally know to whom any post-card is written, given that a post-card can be read by anyone, anyone curious - such as myself; nevertheless, in this instance, with this particular post-card, I suggest one can detect to whom Monsieur D. secretly writes. His name, this secret addressee, is, I suggest, one Walter Benjamin. Improbable, I admit, but the give-away is the God-forsaken word, 'disastrologies'; for, you see, Herr Benjamin was, without doubt, not only the most disastrous of men but also the most astrological.

Herr Benjamin's fascination with the stars can never, of course, be forgotten.

Certainly not by Monsieur D., if only because he and Herr Benjamin were born under the very same star - July $15^{\text {th }}$ their common birth-date. ${ }^{2}$ What is more, the date of this particular post-card, September $27^{\text {th }}$, is Herr Benjamin's death-day, the day of his now-famous suicide, in $1940 .{ }^{3}$ You, sir, may well know the story: the exile, the flight, the mountains, the suitcase, the border, the capture, the delay, the hotel-yes, this hotel. And this disaster, his suicide,

\footnotetext{
${ }^{1}$ Jacques Derrida, The Post Card, tr. Alan Bass (Chicago: University of Chicago Press, 1987), p.115 / Jacques Derrida La carte postale (Paris: Flammarion, 1980), p.126

2 Derrida comments on this in 'Fichus' - Paper Machine, tr. Rachel Bowlby (Stanford: Stanford UP, 2005) p. 175 / Fichus (Paris: Galilée, 2002) p.41. For excellent, though brief, discussions of Benjamin's interest in the stars, see: Susan A. Handelman, Fragments of Redemption (Bloomington: Indiana UP, 1991) p.81; Esther Leslie, Synthetic Worlds (London: Reaktion, 2005) pp.1136; Carol Jacobs, In the Language of Walter Benjamin (Baltimore: Johns Hopkins UP, 1999) pp.97-100

${ }^{3}$ There is confusion as to whether Benjamin died on the night of 25th/26th or the night of 26th/27th, but the latter is preferred in Howard Eiland and Michael Jennings, Walter Benjamin (London: Harvard UP, 2014) p. 674.
} 
had long been written in the stars; Herr Benjamin, you see, had always said he 'was born under...the star of...delay.' ${ }^{4}$ As Monsieur D. once whispered, 'the stars decide. ${ }^{5}$

The stars, sir, above all decide our calendars, our dates; and, as Monsieur also once whispered, 'We have always been preoccupied with dates. ${ }^{6}$ So we have, or at least $I$ have I am, after all, an hotelier, not to mention an occasional scholar. Herr Benjamin, himself a scholar, was certainly preoccupied with what Monsieur D. calls 'the birthday superstition.' Back in 1932 he, Herr B., wrote to a friend, 'I plan to spend the day [July 15] in Nice where I am acquainted with a rather curious fellow [skurrlen Burschen]....I might invite him for a glass of wine.' The friend to whom Herr B. is here writing believes that this 'curious fellow' is Death. ${ }^{7}$

Herr Benjamin, you see, often considered taking his life upon his birthday. In this respect, though, as in so many, he failed, failed to die an anniversary death, a death of true calendrical precision, order, necessity. But then the same might be said of Monsieur, passing away, as he did, on any old day.

Sorry, almost any old day - for it was at least a day in October which is also, in one sense, Herr Benjamin's death-month. True, he died on September $27^{\text {th }}$ but his hotel bill, the official, letter-headed bill is, I confess, dated October $1^{\text {st }}$ and asserts that he 'died today." Herr Benjamin's night was, as it were, smuggled across the monthly border - an old hotelier's trick. To quote Monsieur D., 'I abuse dates'.9

But I digress; for my point, sir, is that Monsieur, a dream-riddled man, does somehow intuit an October correspondence with Herr Benjamin. Once, you see, when visiting

\footnotetext{
${ }^{4}$ Michael W. Jennings, Howard Eiland and Gary Smith, eds., Walter Benjamin: Selected Writings 4 vols. (London: Harvard UP, 1996-2003) 2.713 / Walter Benjamin, Gesammelte Schriften, 7 vols, ed. Rolf Tiedmann and Hermann Schweppenhäuser (Frankfurt: Suhrkamp, 1972-1989) 6.521

${ }^{5}$ Post Card, p.58 / Carte Postale, p.68.

${ }^{6}$ Ibid., p.131 / p.143

7 See The Correspondence of Walter Benjamin and Gershom Scholem, tr. Gary Smith and Andre Lefevere (London: Harvard UP, 1992) pp.9-10 / Walter Benjamin - Gershom Scholem Breifweschel 1933-1940 (Frankfurt: Suhrkamp, 1980) pp.17-19.

8 See Ingrid and Konrad Scheurmann (eds), For Walter Benjamin, tr. Timothy Nevill (Bonn: AsKI, 1993) p.290.

${ }^{9}$ From the 'post-card' text on the back of The Post Card.
} 
Moscow, Monsieur D. remarks that not only does Herr Benjamin's famous 'Moscow Diary' appear in a journal called October but also that he, Monsieur, is staying at a hotel called October, "the grand "official" hotel Oktober.' ${ }^{10}$ Monsieur seems to see much in this coincidence, as if both men might even be called 'Octobrists,' the name given, says Herr Benjamin, to Muscovite infants 'from the moment they can point to the picture of Lenin., ${ }^{11}$ Like the children, both journal and hotel are named after a revolution, the October Revolution; but in the case of our Octobrists, our star-joined Octobrists, what October heralds is not revolution but, sadly, death.

I accept that that not even the prescient Monsieur D. could have foreknown that he would die in October. However, his own father had died in this shadowy month, in 1970; and, indeed, eight years later in, once again, October, Monsieur writes this: 'I know that I am going to die soon (help me). ${ }^{12}$ Help him? But how? Whatever could be done for one already dying? But again I digress. To return to our October theme: I do, sir, consider it not insignificant that when Monsieur D. visits some Paris exhibition of 127 wretched scribbles, each one depicting a coffin and each one obsessively dated, he darkly observes that October is 'the most fertile month for coffins.' It is 'as if,' he murmurs, one 'were preparing for All Souls' Day.' 13

All Souls Day is, I suppose, just one more reason to decipher October as the month for dying. Beware, sir, Hotel October. Or rather, to express all this in a more scholarly manner, it is my humble thesis that the thought of Herr Benjamin is, for Monsieur D., the thought of October, which is to say the thought of death. And this is not just knowable death, death from the past, that of his father, but also unknowable death, death yet-to-come and still

\footnotetext{
${ }^{10}$ Jacques Derrida, 'Back from Moscow, in the USSR,' in Mark Poster (ed.) Politics, Theory and Contemporary Culture (New York: Columbia UP, 1993) p.200 / Moscou Aller-Retour (Paris: de l'Aube, 2005) p. 21.

11 Selected Writings, 2.26 / Gesammelte Schriften, 2.322

12 Post Card, p.164 / Carte Postale, p.178

13 Jacques Derrida, The Truth in Painting, tr. Geoff Bennington and Ian McLeod (Chicago: University of Chicago Press, 1987), p.240 / La Vérité en Peinture (Paris: Flammarion, 1978) p.276.
} 
many years hence - his own. The thought of October is, in this respect, magical thought, astrological thought, dis-astrological thought, as it were. Glass of wine, sir?

We are in November now.

(Jacques Derrida, 1989) ${ }^{14}$

Yes, but we were always in November, even when in October. You see, according to the Gregorian Calendar, our calendar, Moscow's October Revolution actually took place in November. Forgive my pedantry, sir, but it is only according to the older Julian Calendar, then in use in Russia, that the storming of the Winter Palace was an October storm - it was, for us, here to the west of Christendom, a November storm. In short, the hour is later than we think, closer to winter than we think, more nearly an extension of winter herself - an outhouse of palace winter, as it were.

Once again, our magical Monsieur D. is onto this. I have in mind an essay of his upon what he sees as the mystery of dates, an essay that is itself dated, as 'October 14th 1984'; here, notwithstanding the October hour, Monsieur insists we recall the "“constellations of November." 15 These words are, in fact, lifted from a line of so-called verse composed by some poet named Paul Celan; the line, if quoted in full, warns us of 'the late, the hard November stars.' This fellow Celan never said quite what he saw or read in the late November stars, but it might just be guessed or divined by those of us who know our dates. For, you see, Celan, a Rumanian Jew, once happened, back in 1938, to be passing through

\footnotetext{
${ }^{14}$ Geoffrey Bennington and Jacques Derrida, Jacques Derrida, trans. Geoffrey Bennington (Chicago: University of Chicago Press. 1993) p.127 / Geoffrey Bennington and Jacques Derrida, Jacques Derrida (Paris: Seuil, 1991) p.121.

${ }^{15}$ Jacques Derrida, Sovereignties in Question, ed. Thomas Dutoit and Outi Pasanen (New York: Fordham UP, 2005) p.35 /

Schibboleth pour Paul Celan (Paris: Galilée, 1986) pp.64-5
} 
Berlin on, of all days, $10^{\text {th }}$ of November, the day after that hardest-ever November night, Kristellnacht - Crystal Night. Night of Broken Glass. ${ }^{16}$

For the Jews, I think, there is something especially hard inscribed in the November stars. And I am still more decided in this view whenever I recollect the day that Monsieur D., himself a Jew, once stared and stared at what one might call, sir, a 'Novembrist' account of Christian conversion. The conversion is that of the famous Blaise Pascal, and the account Pascal's own; what, though, so captures Monsieur D. is that, when dating the conversion, Pascal does not give just the naked date, 'Monday November $23^{\text {rd }} 1654$,' but instead adorns it with the finest calendrical vestments such as, 'the year of grace,' and 'day of St Clement, Pope and martyr, and others in the martyrology.' As Monsieur D. remarks, 'Pascal thus takes the event in[to] the Christian calendar - not merely Christian as are all calendars hereabouts [chez nous] but overloaded [surchargé] with Christianity. ${ }^{, 17}$

Observe sir, how for a moment, a November moment, Monsieur D. seems quite overwhelmed by Pascal's exquisitely sainted calendar. Now, Monsieur D. was well accustomed to the fact that, hereabouts, chez nous, all calendars are, quite rightly, Christian; but this one, this particular Christian calendar is, for him, all too much, all too Christian. It is a calendar he feels has turned against him, a Christian turn for the worse made still worse, I feel, by the nice calendrical irony that November $23 \mathrm{rd}$ is also the birth-date of his coreligionist, Celan. What we have here, then, is a war, or struggle for November 23rd, a struggle between Pascal and Celan, Christian and Jew. So: to whom, you might ask, does the day belong?

Well, sir, I have my views but, by training, am discreet, and so shall simply beg the question of whether Monsieur D. is mindful of this calendrical contest. I'm not sure. But

\footnotetext{
16 See John Felstiner, Paul Celan (New Haven: Yale UP, 1995) p.10.

17 Jacques Derrida, Beast and the Sovereign, 2 vols., tr. Geoffrey Bennington (Chicago: University of Chicago Press, 2011) 2.209/ Seminaire. La bête et le souverain, 2 vols (Paris Galilée, 2010) 2.294
} 
even if it is not in his crowded head, the contest is, I think, somewhere hereabouts, somewhere in the hard November stars; for, you see, as Monsieur continues to labour over Pascal's pious text he writes this:

After the date so Christianly specified in the history and calendar of Christianity, [there is] a single word, in the middle of the line:

Fire [feu]

This word 'fire' is...isolated, alone,... [and so] I'm.... sure...I cannot interpret it in a decidable way, between the fire of glory...or that [which] still smoulders under the ashes of some cremation (Aschenglorie). ${ }^{18}$

Aschenglorie, or 'Ashglory,' if you will, is, by the way, a dark invention of the macabre Celan; in the blink of an eye, you see, Monsieur D's hard-labouring over Pascal's November $23^{\text {rd }}$ has led him from 'the history and calendar of Christianity,' no less, to the 'ashes of cremation' - that is to say, to all that now remains of Judaism. How? Why? Well, sir, the clue is in the word 'Fire' which here has, I feel, a secret Christian provenance; for, you see, the date, the date of Monsieur D.'s hard labour, is Wednesday March $5^{\text {th }} 2003$, that is to say Ash Wednesday. Monsieur is, I accept, silent on this; but three years before, in March 2000, he does remark upon how the Pope, the Holy Father himself, undertakes in his Ash Wednesday Homily 'an act of repentance without precedent' - repentance in particular for the fact that the Church apparently did not protest, and I quote, 'the mistreatment of the Jews. ${ }^{, 19}$ For Monsieur D., the ash of Ash Wednesday must have somehow mingled within it the plenteous ash of the Final Solution - or what some, their heads full of martyrs, now style as conflagration or even holocaust.

Which returns me to Herr Benjamin. He too, you see, seems to think, or rather forethink, fire. Consider, sir, what I believe to be an elaborately encoded newspaper article of his; one that appeared, under a pseudonym, in the Frankfurter Zeitung in 1935. The article is sub-titled 'Reflections of Carnival Time in Nice' and begins thus: 'It was Shrove Tuesday in

\footnotetext{
${ }^{18}$ Ibid. 2.212 / 2.298

${ }^{19}$ Jacques Derrida, The Death Penalty, 2 vols., trans. Peggy Kamuf (Chicago: University of Chicago Press, 2014) 1.244 / Séminaire. La peine de mort (Paris: Galilée, 2012) 1. 332.
} 
Nice [and] I had...turned my back on the carnival' - and so he does, thereby turning his back on a carnival that, along with the article itself, climaxes in fire, the wondrous, festival fire of Ash Wednesday. ${ }^{20}$ To quote, if I may, the final sentence:

a rocket rose into the sky; a cannon...resounded: [this was] the signal to burn the fifty-seventh Carnival Prince, whose funeral pyre must be extinguished to the last spark before Ash Wednesday begins.

Now sir, the question is: what is it about our fiery Mediterranean carnival that causes Herr Benjamin to turn away? No idea? None? Well, we are, I believe, given clues, cryptic clues - among them: the 'carts [that]...look like an armed formation'; the streets that are 'cleared of all secular traffic'; the floats that double as 'bastions' behind which the carnival performers 'wage...battle'; and last, but not least, my favourite: the 'Fairground Chronicler' who is, we read, 'a demonic fellow.' So: can sir crack the code? No? Well, I think I can; for this Shrove Tuesday in Nice, this day of Christian carnival, is, in truth, the carnival that was once the Third Reich. Remember the Reich, sir? The armed formations, the clearing of streets, the battles waged? No? Well, it might just come back to you, sir, when I add that in this fine article of Herr Benjamin's there is an onlooker, a man called simply 'The Dane,' who coolly observes that 'the Carnival is an exceptional state' - the word in German being Ausnahmezustand, a word that, as Herr Benjamin knew full well, was being brought to full bloom by the Third Reich, or at least its legal theorists, apologists. ${ }^{21}$ Their point, you see, was that the State can, on occasion, find itself in a situation, or condition that is so exceptional, so extraordinary, as to legitimate the seizure of absolute power by One Strong Man. In short, if you will, Here Comes the Demonic Fellow - not to mention the funeral pyre.

Ah yes - this pyre, this fire, this extinguishing 'to the last spark,' it does, in part, put me in mind of the Final Solution. It is, in other words, almost as if Herr Benjamin here

20 Walter Benjamin, 3.25-31 / 4.763-771

${ }^{21}$ The word is particularly associated with Carl Schmitt, with whom Benjamin infamously corresponded. 
somehow foresees one very particular day - namely, January $20^{\text {th }} 1942$. This, sir, as you know, is that day on which, at a fine snow-bound house in Wannsee, a true Berlin winter palace, sir, a meeting was held to address the Jewish Question. Of course, strictly speaking, Herr Benjamin does not actually live to see this day - certainly if we are, as Monsieur D. puts it, to 'rely...on the objective dates of the Wannsee Conference of 1942 and Benjamin's suicide on the Franco-Spanish border in 1940. ${ }^{, 22}$ But then Monsieur himself does not actually rely on these dates, perversely adding that 'the chronology of such events cannot be taken for granted.'

Curious. Though, in a sense, Monsieur D. is correct. For the days of the Reich were one in which 'the time,' to quote another Dane, was somewhat 'out of joint' - exceptional, as it were. Our Herr Benjamin had, I think, his own very particular view on this exceptional and almost, as it were, a-calendrical moment; he called it, I believe, a 'Nazi hell' or Nazihölle within which one finds 'the man [whom] no one needs, whose days even the calendar stops counting. ${ }^{23}$ Strong words, but hats off to Herr Benjamin for once again seeing what was to come - namely, the man, or rather men, whose final months, weeks, and days were not deemed worth calendrical measurement. Herr Benjamin himself, however, did not die such a death. One advantage, sir, of killing yourself in a hotel is that your death is recorded, dated, costed. A hotel suicide will never be, to quote Herr B., 'dropped from the calendar., ${ }^{24}$ Another glass, sir?

\section{Editorial Note:}

The reader may be interested to know that the owner of the hotel in the Pyrenees, on the French-Spanish border, where Walter Benjamin died, Juan Suñer, was known to be not only 'not reliable with dates' but also 'on good terms with ... the Gestapo. ${ }^{25}$

\footnotetext{
${ }^{22}$ Jacques Derrida, Acts of Religion, ed. Gil Anidjar (London: Routledge, 2002) p.260 / Jacques Derrida, Force de loi (Paris: Galilee, 2005) p.71

${ }^{23}$ Selected Writings, 4.132 / Gesammelte Schriften, 3.537

${ }^{24}$ Ibid., 4.336 / Ibid., 1.643.

${ }^{25}$ See For Walter Benjamin, pp. 290, 269.
} 
You see, sir, the Final Solution meant, I gather, that many a Jew died a dateless death. Two, in fact, were parents of this fellow Celan. It is, I presume, why he makes such a fuss of January $20^{\text {th }}$ - note, sir, how he often speaks, or rambles, about ' $a 20^{\text {th }}$ of January' and even ' $m y 20^{\text {th }}$ of January,' as if to say that his parents had actually died on January $20^{\text {th }}$, January $20^{\text {th }} 1942 .{ }^{26}$ And in a sense they did; along with all the others. We are, this fellow seems to say, in January now, and always will be.

If so, then what of Herr Benjamin? Would it have been more correct to have recorded as his death-date not September $27^{\text {th }} 1940$ but January $20^{\text {th }} 1942$ ? Well, yes, perhaps sir certainly if we were to follow Monsieur D.'s line that 'the chronology of such events,' indeed of these very particular events, 'cannot be taken for granted.' I think now, by the way, of an especially moving question that Monsieur poses à propos the $20^{\text {th }}$ of January - it is this: 'Who walked through the mountains, on this date?' ${ }^{27}$ How I love this question, and wait upon it, presuming that the answer will surely, at some point, turn out to be 'Herr Benjamin,' $m y$ Herr Benjamin, he who, in his final days, walked our very own Pyrenees. But no, no - to my chagrin, Monsieur D. here makes no mention whatsoever of dear old Herr Benjamin, hobbling along with his loaded briefcase. It is as if poor Herr B. did not actually come our way, our mountain way - least not 'on this date,' the $20^{\text {th }}$ of January. Herr B., it seems, is one Jew who does not have a $20^{\text {th }}$ of January. Indeed, you might say, sir, that he does not even have a $20^{\text {th }}$ of January - or at least not according to Monsieur D's so-called 'datebook. ${ }^{28}$

But then, Monsieur is a complicated man, one for whom even the $20^{\text {th }}$ of January is never purely and simply itself but always entangled with quite another date - in particular, another date from quite another calendar, the Jewish one. This other, Jewish date is the $13^{\text {th }}$

\footnotetext{
${ }^{26}$ See Paul Celan, Collected Prose, tr. Rosmarie Waldrop (New York: Routledge, 2003) p.53

27 Sovereignties, p. 5 / Schibboleth, p 17.

${ }^{28}$ Derrida often refers to a 'datebook' [agenda] - see, for example, Post Card, p.126/ Carte Postale, p.138
} 
day of the Jewish month of Adar, the very day on which, according to the book of Esther, King Xerxes of Babylon orders the elimination of every Jew within the kingdom. To quote Monsieur D., 'the acts are sent...to all the towns...to exterminate...all...Yehudim...in a single day, the $13^{\text {th }}$ of the $12^{\text {th }}$ lunar cycle...the cycle of Adar.' The plan is for what Monsieur D. fashionably calls 'a holocaust'. ${ }^{29}$ Whatever, it is a fate from which the Yehudim are, in the end, excused; the order being reversed and none killed. The 13th of Adar is, you might say, a miraculous $20^{\text {th }}$ of January, a miracle from deep within the Hebrew calendar.

Perhaps so - if miracles there be, sir; though one miracle I'd never dispute is, in fact, the Hebrew calendar itself, it being a miracle of numeration and, indeed, the dark magic thereof. And something of this magic is right here, before our very eyes; you see, Monsieur D. sets down his thoughts upon the $13^{\text {th }}$ of Adar in a post-card that is dated ' 7 th September 1977,' a date over which, as Monsieur himself remarks, 'the figure 7 reign[s],' and does so absolutely since even the name "“September"...includes...[the] number...in its name' - sept for 7, of course. ${ }^{30}$ Seven, sept, seventy-seven; here reigns the number of what is, for Jews, the Sabbath, the day on which God reclines and rests.

By the way, Monsieur D. often has the Sabbath in mind. 'I can see the figure 7,' he says, 'see it radiate over [all] our great events.' And, sir, what event could be greater than the rest of God? After all, this rest, I hear, is perpetual. So says even St Augustine, he for whom the Sabbath is, as Monsieur D. recalls, 'the...day...without...evening., ${ }^{31}$ In Genesis, you see, whilst days one to six each end with an evening, in the case of day seven there is no mention of evening. Not a word. None. And how I love to dream of this, this endless rest.

\footnotetext{
${ }^{29}$ Post Card, p.71 / Carte Postale, p.80

${ }^{30}$ Ibid., p.167 / Ibid., p.183; Sovereignties, p.37 / Schibboleth, p.68.

${ }^{31}$ Jacques Derrida, p.275 / Jacques Derrida, p. p.255
} 
But alas, sir, a dream it is; for, as Monsieur D. suspects, there is, hereabouts at least, only an endless deferral of rest - 'an evening of rest that never arrives. ${ }^{32}$

A dispiriting thought, this thought of rest-less rest, of pure un-Sabbath. And, sadly, it returns to Monsieur D. when he thinks of 1940-1942, those years in which, in occupied Belgium, his friend Professor Paul de Man is posthumously accused of having written against the Jews, in a pro-German paper, called Le Soir. 'The Evening,' that is. What here betrays the rest-less thought, the thought of rest-less rest, is that Monsieur D.'s reflections on all that his learned friend once wrote in Le Soir take the form of 'seven diary fragments,' each and every one of which is composed on a Saturday, the Sabbath. ${ }^{33}$ The very day on which, of course, the Jewish Monsieur D. should not be writing.

But then Monsieur D.'s sense of time is, I fear, invariably in rags, for as his enemies circle they condemn not simply his unfortunate friend but the very epoch, or era that, it is said, the two of them founded. I refer to what his enemies sometimes call, and I quote, 'the Era of Deconstruction.' But no! protests Monsieur D., no! 1942 was all so long ago; back then, he cries, "'Deconstruction"...was [still] at year minus twenty-five...!'34

Let us begin again.

(Jacques Derrida, 1967) $^{35}$

'Year minus twenty-five' - quite; for you see, sir, if 1942 is year minus twenty-five then year zero is 1967, Monsieur D's annus mirabilis, the year he first broke upon the world desperately whispering, 'Let us begin again. ${ }^{36}$ By which, I say, he means begin even time

\footnotetext{
32 Ibid. p.273 / Ibid., p.253

${ }^{33}$ See Jacques Derrida, 'Biodegradables: Seven Diary Fragments,' tr. Peggy Kamuf, Critical Inquiry 15 (1989) 812-73.

${ }^{34}$ Ibid., p.820.

${ }^{35}$ Jacques Derrida, Speech and Phenomena, tr., David B Allison (Evanston: Northwestern UP, 1973) p.142 / Jacques Derrida, Marges de la philosophie (Paris: Minuit, 1972) p.13

${ }^{36} 1967$ is so-called by Benoît Peeters in Derrida. A Biography (London: Polity, 2013) primarily because in this year Derrida published three major books.
} 
again; for that's all they ever do these Parisians, famously firing at every damned clock they can find. They dream, though, not of no calendar but, as Herr Benjamin once observed, of a 'new calendar' - and so it is with this thing they call Deconstruction. ${ }^{37}$ It too harbours no desire to altogether annihilate the calendar.

Note, sir, how Monsieur D. rounds upon his enemies, accusing them of speaking 'as if what had happened to de Man in 1940-42 could constitute a "turn"... of the "deconstructive project" in 1988!'38 Do these clowns not, he wonders, have calendars? Do they not know that 1940 comes before 1988 and not after?

But what, you might ask, of Monsieur's protestation, made just two year later, that 'chronology cannot be taken for granted'? And is that not, you might add, even more the case on a Sabbath, the very day on which he writes all this - in his diary? Well, yes it is, sir, but you see Monsieur D. is not keeping his Sabbath. Simply by virtue of writing, of hammering at the old keyboard, he is also hammering at the Sabbath and thus exposing it to the very stain of time, to days-with-evenings, calendrical days. In short, for Monsieur D, I fear, there is no pure Sabbath, no day of absolute rest from time, no place where dates cannot reach him, in particular the dates of 1940-42. The war, you see, laid waste to the Sabbath was, in fact, I say, a war upon the Sabbath.

And our Herr Benjamin, by the way, he knew this, knew this well. In 1939,

September $21^{\text {st }}$, he writes this, from an internment camp in France:

Dear Miss Monnier,

Your concierge may have told you that I came on Saturday - eight days before war was declared - to say goodbye. Unfortunately, you were not there.

My address is [now] camp des travailleurs voluntaires, groupement 6 Clos St Joseph NEVERS (Nievre).

I am doing as well as can be expected....My physical strength, however, is worthless. I collapsed on the walk to our camp. The camp doctors gave the following order: 'at ease - rest.' [au repos]

I remain faithfully yours,

\footnotetext{
${ }^{37}$ Selected Writings, 4.395 / Gesammelte Schriften,1.701.

38 Derrida, 'Biodegradables,' 827.
} 
Walter Benjamin ${ }^{39}$

I cherish this letter, and often re-read it. It reveals, you see, how such was the almighty force of Herr Hitler's assembled armies that even before war, even before the great mobilisation, the Sabbath was already condemned: 'I came on Saturday...to say goodbye but you were not there.' And, indeed, with Herr Hitler's men now closing in, it is clear that Sabbath rest is reduced to nothing save irony, for when the camp doctors bid Herr Benjamin to 'be-at-rest' their cry, au repos, is but an ironic echo of the military command 'at ease.'

There is, though, another reason why I treasure this letter - namely, that it's written from a place called Nevers, and if there were one place in the world that might have offered shelter to the Sabbath, for the day-that-is-not-a-day, it would surely be Nevers - Nevertown, Neverland, Hotel Never, if you will. Though not, alas, for Herr Benjamin; for him, rest here comes as but the parody of a command, a parody made all the more telling given that the Sabbath was, in the Beginning, precisely that - a command: 'Six days shalt thou labour but the $7^{\text {th }}$ day is the Sabbath of the Lord thy God' (Exodus 2.10). When the camp-doctor instructs Herr Benjamin to be au repos his voice is a short, sharp reminder of not only the military but the divine, the voice of the Almighty Himself. The very name of command, authority.

Command, authority - sir looks surprised. But why so? Our world is calendrical and the word 'calendar' hails from the Latin Calandrae, which is itself founded on kal, meaning 'to call' or 'proclaim,' thus quick-marching us straight back to imperial Rome, the public square, the monthly loud-hailing of the 'order of days.' As even Monsieur D. has noticed, 'the institution of the calendar...permits one to call out, [or] to class. ${ }^{40}$ And the same may be said of dates; here too etymology is our guide, the word 'date' coming to us from data

\footnotetext{
${ }^{39}$ The Correspondence of Walter Benjamin, tr. Manfred and Evelyn Jacobson (Chicago: University of Chicago Press, 1994) pp.613-4 / Walter Benjamin Briefe, 2 vols. (Frankfurt: Suhrkamp, 1978) 1.827

${ }^{40}$ Sovereignties, p.44 / Schibboleth, p.81.
} 
littera, meaning 'letter given,' the beginning of some ancient clearing of the legal throat. Both dates and calendars have, you see, what Monsieur D. would call the "force of law."41 Don't forget that. I never do. It is, perhaps, why I am so drawn to calendars, so drawn to read the world calendrically; for to do so is to read the world decisively, authoritatively - that is to say, with force. With what the Germans call Gewalt. Hence, Walten, to rule.

Walten, a fine word. Not, of course, to be confused with 'Walter'; though that is exactly what Monsieur D. does. I think now of the occasion Monsieur once eyed some scribbling of Herr Benjamin's wherein the penultimate word is waltende. Monsieur D. promptly declares that he here sees the name 'Walter,' as if Herr B. was thus secretly leaving his signature, giving but also withholding his name. ${ }^{42}$ Just as, of course, some gentlemen do when visiting hotels.

But I digress, digress from just how peculiar it is that Monsieur sees Walten as 'Walter' - Herr B. being, you see, a man of so little physical force, so very little. It is, indeed, all so peculiar that I have spent many a day scrutinizing exactly what Monsieur says about this final signature-sentence, in particular how he likens it, in an unmistakably Jewish flourish, to 'the evening shofar.' ${ }^{43}$ And this, this flourish, is now beginning to make some kind of sense; for even I, but an amateur scholar, can fathom how Monsieur, a sentimental man, might just associate the calamitous Herr Benjamin with the lachrymose sound of the horn that is blown to mark the termination of Hebrew day.

But there is more, more to Monsieur D's plangent simile. For it extends to become, and I quote, 'Like the evening shofar, but on the eve of a prayer' - not 'on the eve of a day,' please note, as if to say that the day to come is itself somehow a prayer, a day made of prayer, of nothing but prayer. And yes, I can make rough, unpolished sense of this as well; for, you

\footnotetext{
41 See Acts, pp.230-98 / Force, passim.

42 Ibid., p.262 / p.72.

${ }^{43}$ Ibid., p.292/ p.133.
} 
see, Herr Benjamin, in his final hours, as night crawled toward day, was heard to pray, or at least to plead and beg as four times he resorted to the hotel telephone. Whom he was calling we do not know, but even to those who didn't speak German it was clear that the Jew in the lobby was begging. Equally clear was that no-one heard. And this returns me to Monsieur D. for, to quote him in full, Herr Benjamin's signature-sentence is, 'Like the evening shofar on the eve of a prayer one no longer hears. No longer heard.' The prayer, then, of which this day-to-come consists is, to be precise, a prayer that is not heard. And I humbly suggest that the world knows of just such an unheard prayer, it being that most famous un-prayer of all: 'My God, my God, why has thou forsaken me?' And, of course, there is a day made out of this cry, a day that is this cry; but it can be found only within Christian calendars, shofarfree calendars - the day is Good Friday. One last glass, sir?

I am not looking beyond Easter.

(Walter Benjamin, January 7, 1935) ${ }^{44}$

Herr Benjamin was, you know, born on a Friday and, indeed, died on a Friday, albeit only just, it being in the early hours, still dark. He was, therefore, Friday's Man; or, if you will, Man Friday. I think, in this connection, of Robinson Crusoe. As does Herr B. himself, in fact: once, when recalling something that terrified him as a child, he whispered, 'my response was much like the one I later had to the illustration in Robinson Crusoe showing Friday at the spot where he first discovers the... skulls. ${ }^{45}$ How odd that Herr Benjamin confuses Friday with Crusoe, it being in fact Crusoe and not Friday who chances upon the skulls; whatever, for Herr Benjamin here read Man Friday. Indeed, seeing that our Herr Friday, as it were, finds himself among skulls, I would dare to suggest we are, again, not far from Good Friday,

${ }^{44}$ Correspondence, p.472 / Briefe, 1.640

45 Selected Writings, 3.398 / Gesammelte Schriften, 4.277 
the Friday endured by Our Lord at Hotel Golgotha - literally, 'place of the skull.' To conclude, if I may: Herr Benjamin is Man Friday in the strongest possible calendrical sense.

And that's exactly why I am so drawn to Wednesday March 12th 2003, almost the last of Monsieur D.'s Paris seminars, a weekly waltz. This particular waltz just happens to have as its theme Robinson Crusoe, and what catches my wakeful eye is that in the middle of the dance Monsieur D. suddenly declares himself 'a French animal...every Wednesday sniffing out the footprints... of an improbable Friday. ${ }^{46}$ Here, as if at some mournful masked-ball, Monsieur D. plays Crusoe - that is to say, an islanded soul. It is true, I accept, that he also here declares 'there is no world...only islands,' as if to say that islands mean final and absolute loneliness; upon Crusoe's island, however, there $i$ s to be a companion - Friday. ${ }^{47}$ By wearing, then, the Crusoe-mask, Monsieur D. signals his hope, even at this late hour, of yet discovering that he is not utterly alone in the world, that somewhere out there is a Friday, however improbable. It is, though, my conviction that, sadly, our long-dead, stone-dead Herr Benjamin is he.

Our two men are, you see, twins of a sort, ragged sort, sharing as they do a vagrant way through the world. So much so that when Monsieur D. dreams of hapless Herr B. 'Poorly received in his country... almost unknown in the land of exile, France' - he might almost be dreaming of himself. ${ }^{48}$ Likewise, when Monsieur whispers of shuffling from one hotel to another - 'I travel... with strange writings in my case [valise]' - he might as well be whispering of Herr B. ${ }^{49}$ And Monsieur D. clocks all this, clocks that Herr Benjamin is his improbable Friday. One Wednesday, in the Crusoe seminar, he all of a sudden stops, like a clock in fact, and fixes upon our word, my word, Walten: 'What,' he inquires, 'does...

\footnotetext{
${ }^{46}$ Beast, 2.240 / La bête, 2.335 .

47 Ibid. 2.9 / Ibid., 2.31.

${ }^{48}$ Truth, p.177 / La vérité, p.204.

49 'Moscow,' p.202 / Moscou, p.26.
} 
Walten mean? Why Walten?'50 It is as if he has seen not so much a word as a ghost, which, in a sense he has, for just a few Wednesdays prior, he murmurs this: 'So much for Walten and for those who are so-named [s'appellent] - we know at least one of them - Walter. ${ }^{51}$ Monsieur D.'s weekly Wednesday search for Friday here leads, alas, to the catastrophic Herr Benjamin. The footprints turn out to be his, Herr B's.

Just as they do some years before when Monsieur D. wanders on to an actual island indeed, to be precise, into an hotel on an island: 'Date: 28 February 1994. Place: an island, the isle of Capri. A hotel. ${ }^{52}$ This date, by the way, is a Monday but Monsieur D. is talking of Friday, Good Friday, or rather Professor Hegel's famous 'speculative Good Friday'53 - a fine, orderly, philosophised Good Friday. Again, then, our islanded Monsieur seeks out an improbable Friday. This, though, is not just any island, since Capri in 1924 was, for six months, inhabited by Friday himself, our Man Friday, Herr Benjamin, he whose Friday death would be suffered alone, second floor, rear room. Herr Benjamin, you might say, thereby endured a Good Friday that was, alas, neither speculative nor orderly but rather a hard fact of shaking flesh.

Monsieur D. whilst on Capri says nothing about Herr Benjamin; nevertheless, it is to Herr B.'s Good Friday, rather than Professor Hegel's, that Monsieur is finally lured Monsieur, remember, is an 'animal sniffing out Friday,' thus on the trail of a Friday that stinks. And Benjamin's Good Friday most certainly stank. Why else, sir, does his posthumous bill include the cost of dis-infecting the room $?^{54}$

\footnotetext{
50 Beast, 2.252, 256 / La bête, 2.350,355

51 Ibid., 2.44 / 2.78 - translation modified.

${ }^{52}$ Derrida and Vattimo (eds), Religion (London: Polity, 1998) p.3 / La Religion (Paris: Seuil, 1996) p.11

53 Ibid., p. 15 / p24

${ }^{54}$ See For Walter Benjamin, p.291.
} 
It is a Sunday.... and Sunday is not just any day. (Jacques Derrida, April 1993) $^{55}$

In any Christian calendar, Friday, day of death, sniffs out Sunday, day of resurrection. And so it is even with Monsieur D., he being, by his own admission, 'a French animal' and, to that extent, a Christian animal. This is why, you see, he is so mesmerised by the way that a certain Herr Marx, when talking revolutions, keeps pointing out that they occur on Sundays. Our Monsieur Animal, as it were, broods on this, then howls aloud, 'Hegel had...named a...speculative Good Friday, [but] Marx gives... what is seen on the Lord's day.' And what is that? Why, says Monsieur, it is 'the awaited apparition, the return of the dead.' For Monsieur D, what makes Sunday 'not just any day' is the possibility of spectral or esoteric encounter.

And this is clear, very clear, in one particular post-card of his. It is, in fact, a hymn to post-cards, a hymn to how they so mix and mingle at that point of perpetual collection and sorting otherwise known as the humble post-office: 'For me,' writes Monsieur, 'the postoffice is a church in which secret rendezvous are given, Notre Dame on a Sunday afternoon. ${ }^{56}$ As sir may have noticed, this paean to the post-office is also a paean to Sunday - the day of resurrection, the day of the returning dead here brilliantly re-imagined as a day of innumerable secret encounters.

Ah, how I will always treasure the ingenuity of this post-card, Monsieur D.'s quite dazzling attempt to perpetuate the dream that is Sunday. However, and I hate to be indelicate, sir, but I must, sadly, point out that Monsieur himself dies on a Saturday. At the last, he simply doesn't make it to Sunday. Sunday is just beyond reach. Indeed, Monsieur D. always knew this. I think of something he once wrote concerning Dr Sigmund Freud and the

\footnotetext{
${ }_{55}^{5}$ Jacques Derrida, Specters of Marx, tr. Peggy Kamuf (London: Routledge, 1994) p.118 / Spectres de Marx (Paris: Galilée, 1993) p.192

${ }^{56}$ Post Card, p.69 / Carte Postale, p.77
} 
death, in Hamburg, on January 25th 1920, of his daughter Sophie - she who was called, as Monsieur observes, "'the Sunday child." 57 It is, as we know, sir, hard enough to endure the death of one's child, but what makes this particular death still harder is that Dr Freud and his wife, who live in Vienna, could not get to their daughter's cremation - the reason: 'the railroads were shut down.' To cite Dr Freud himself, 'our poor Sunday child is to be cremated tomorrow' and yet there is, as Monsieur D. murmurs, 'no train to go to the deceased.' ${ }^{58}$ Sunday's child is dead, sir, and cannot be reached. No trains are that way running. There will, then, be no rendezvous, no encounter with the dead. The train to Sunday does not depart, let alone arrive.

It is still Sunday.

(Jacques Derrida, April 1993) $^{59}$

No, no. It is Saturday and will always be Saturday. We will never make it to Sunday. The trains cannot be trusted, certainly not Sunday trains. Ask Herr Benjamin.

On December 28, 1879...the regular...train left Edinburgh for Dundee....It was Sunday...one of those stormy Scottish days, [and half-way across the Tay] bridge ...the train...descended to the water beneath. There were no witnesses.... ${ }^{60}$

By the way, neither were there any witnesses to Herr Benjamin's own descent, no one to see the passing of Friday's Child, his painful Friday passing. His final Friday was, if you will, a Friday that could never make it to Sunday; for without witnesses there was no-one to record his final words, no-one to smuggle them, and thus him, past death - that curious fellow, Death. It is true, as I say, that Herr B. made four final telephone-calls, but we have no idea to whom he spoke, and whoever it was they could not, sir, possibly count as witnesses.

\footnotetext{
${ }^{57}$ Ibid., p. 329 / Ibid., p.350

${ }^{58}$ Ibid., p.331 / Ibid., pp.351-2

${ }^{59}$ Specters, p.118 / Spectres, p.192

${ }^{60}$ Selected Writings, 2.566 / Gesammelte Schriften, 7.235-6
} 
-'Someone has just called me on the telephone - it's nasty’ (Jacques Derrida) ${ }^{61}$

-Silence!

-'A telephone-call, the news of one dying' (Jacques Derrida) ${ }^{62}$

-Silence, I say.

-'I've just hung up... of no interest this suicide' (Jacques Derrida) ${ }^{63}$

-Indeed, indeed. So bid farewell to Herr Benjamin.

-'Adieu or au-revoir?' (Jacques Derrida) ${ }^{64}$

-Pardon?

-'Adieu or au-revoir to Benjamin?' (Jacques Derrida)

-Well, you tell me. Which would you choose? What do you believe? At the end. Go on: what's your final word? What is it?

-'I...leave him the final word' (Jacques Derrida)

-Whom? Leave whom the final word?

-'Benjamin...I...leave Benjamin the final word' (Jacques Derrida)

-Ah! And, pray, what does he say?

-'It's cold in this hotel.' ${ }^{65}$ (Jacques Derrida)

- No!

-'The hotel is sinister.' ${ }^{66}$ (Jacques Derrida)

- No!

-'I am going to die soon, help me.' (Jacques Derrida)

${ }^{61}$ Post Card, p.145/ Carte Postale, p.158

${ }^{62}$ Jacques Derrida, p.207 / Jacques Derrida, p.193

${ }^{63}$ Post Card, p.233/ Carte Postale, p.250

${ }^{64}$ Acts, p. 292 / Force, p.132.

${ }^{65}$ Post Card, p.180 / Carte Postale, p.194

${ }^{66}$ Ibid., p.220 / Ibid., p.236 
-Nonsense, damnable nonsense. You imagine that you ventriloquise Herr Benjamin, that he speaks not merely to you but through you, and even now, as if it were not adieu to Benjamin but only au-revoir. You speak, in short, as if it were Sunday. And it is not. It may just be Sunday on Sundays, but for six days out of seven, for six-sevenths of human time, of human history, it is anything but Sunday. Understand?

Pause

-'It is -

-Yes?

-'It is still Sunday. ${ }^{67}$ (Jacques Derrida)

'Porosity is the...law of...life.... A grain of Sunday is hidden in each weekday' (Walter Benjamin). ${ }^{68}$ 